\title{
Malheur National Wildlife Refuge, Public Land, and the Spaces of Whiteness
}

\author{
Joshua Smith * \\ Department of Communication Studies, The University of Kansas, Lawrence, KS, United States
}

In this essay, I examine the 2016 takeover of Malheur National Wildlife Refuge. The principal instigators of this occupation, the Bundy family of Nevada, pointed to federally owned public lands as the primary reason for their takeover, citing the allegedly unconstitutional government ownership of these lands. I contend that the Bundys' arguments about public lands exemplify rhetorical strategies that further one of the primary ends of settler colonialism; the remaking of land into property to better support white settlers' claims to that land. I hold that the Bundys remake land by defining the land's meanings following

OPEN ACCESS

Edited by:

Mariko Oyama Thomas,

Central New Mexico Community

College, United States

Reviewed by:

José Castro-Sotomayor,

California State University, Channel

Islands, United States

Eric Karikari,

Towson University, United States

Ailesha Ringer,

Metropolitan State University,

United States

*Correspondence:

Joshua Smith

j.smith16@ku.edu

Specialty section:

This article was submitted to

Science and Environmental

Communication,

a section of the journal

Frontiers in Communication

Received: 15 June 2021 Accepted: 29 November 2021

Published: 17 December 2021

Citation:

Smith J (2021) Malheur National Wildlife Refuge, Public Land, and the

Spaces of Whiteness.

Front. Commun. 6:725835.

doi: 10.3389/fcomm.2021.725835 the logics of settler colonialism in three specific ways: privatization, racialization, and erasure. First, I examine the family's arguments about the constitutionality of federal land ownership to show how the Bundys define public lands as rightfully private property. Second, I examine the ways that the Bundys racialize land ownership and how, in conjunction with arguments about property rights, the family articulates land as the domain of white settlers. Third, I discuss how the Bundys further colonial logics of Native erasure. That is, the family defines land in ways that portray Native Americans as having never been on the land, and as not currently using the land. I argue that these three processes render meanings of land-as private property, colonized, and terra nullius - that rhetorically further the operation of settler colonialism.

Keywords: public lands, settler colonialism, Malheur, Bundy family, whiteness

\section{INTRODUCTION}

On January 2, 2016, Malheur National Wildlife Refuge (MNWR) near Burns, Oregon, was taken by force by a group of armed anti-government extremists. Five years and 4 days later, when the US Capitol building was stormed and briefly occupied on January 6, 2021, connections were quickly drawn between D.C. and Oregon. As Segerstrom (2021) wrote for High Country News, "It's not hard to trace the links between Malheur and Washington; familiar insignia, instigators and ideologies fueled both anti-government actions" (2021, n.p.). Segerstrom was not alone in making this connection; Siegler (2021), writing for NPR, noted the similarities between the Oregon incident and the Capitol occupation, while Bernstein (2021) of The Oregonian wrote that Malheur was a "dress rehearsal" for what happened at the Capitol (Bernstein, 2021; Siegler, 2021).

Though the motivations behind the two occupations were different--Malheur was said to be a protest in support of two local ranchers' legal troubles, while the Capitol riot was an attempt to overturn the recent presidential election--the two incidents shared commonalities beyond "familiar insignia, instigators and ideologies." Specifically, the occupations of both Malheur and the Capitol building shared assumptions about public spaces, or that white men, in particular, are seen as 
belonging in those spaces. Many were quick to point out the privilege whiteness gave those involved in Capitol occupation, including Joe Biden, who, less than 2 weeks from his inauguration, noted the next day that "You can't tell me that if it had been a group of Black Lives Matter protesters yesterday they wouldn't have been treated very differently than the mob of thugs that stormed the Capitol. We all know that is true" (Chason and Schmidt, 2021, n.p.). As Chason and Schmidt (2021) of The Washington Post make clear, BLM protestors and the January 6 mob were indeed treated much differently (2021). Similarly, many were quick to point out how the Malheur occupiers were treated differently than Indigenous water protectors at Standing Rock in North Dakota. Kirby Brown (2016), a citizen of the Cherokee Nation and associate professor at the University of Oregon, wrote "county, state and federal officials have mobilized the full weight of state power against unarmed indigenous water protectors" at Standing Rock, while one protestor noted that "If native people were armed like the [Oregon] militia. we would be killed" (Brown, 2016, n.p.; Levin, 2016, n.p.). The primarily white instigators in both Oregon and D.C. acted as they did, in part, because they regarded the spaces as inherently theirs. ${ }^{1}$

The occupation of MNWR was a rhetorical reclamation of public land, an action that I hold is deeply rooted in settler colonial understandings of land. In US settler colonial logics, land and human relationships to land are primarily understood through the Anglo tradition of property rights descending from John Locke (Tuck and Yang, 2012; Taylor, 2016). The occupiers' claim that they were going to help the people of Harney County "take back their land," fit neatly into an understanding of land as property. Given the US context, it is a logical step, and a short one, to also articulate settler colonialism as a logic of whiteness. That is, settler colonial notions of property provide white settlers with an assumed inherent right to the land (Inwood and Bonds, 2017; Boggs, 2019). In particular, the occupiers' arguments about land demonstrate the ways that white masculinity is enacted in settler colonialism, and how land ownership is ideal of white settler masculinity. Such logics informed the occupiers' arguments about land and their takeover of MNWR.

If we are to take seriously the suggestions that the Capitol occupation in January 2021 had its origins at MNWR, we need to examine the roots of that earlier conflict. In particular, we need to examine how the MNWR occupiers talked about and understood a specific space: public lands. The refuge occupiers assumed an inherent white right to the land, a right they thought gave them--as largely white men--carte blanche to treat the land as they wished. Put otherwise, the MNWR occupiers understood land primarily in terms of private property and "productive" economic use. Defining land in this way is a feature of settler colonialism, an on-going structure that is central to the knowledge systems of whiteness (Wolfe, 1999; Bonds and Inwood, 2016). The occupiers made specific arguments about

${ }^{1}$ For rhetorical examinations of the uses of public space for protest, see: Endres and Senda-Cook (2011), Gruber (2020), and O'Byrne and Endres (2021). public lands that define lands in terms of private property, whiteness, and economic production: they argued that the Constitution limits federal land ownership, and that the intention behind these limits was to "quickly dispose the land and resources to the local people, where it is most safe" (Bundy, 2014a, n.p.); the occupiers racialized land ownership, in part, by arguing that Native Americans have "lost" their claim to land (Keeler, 2017, p. 3); and finally, the occupiers argued that "useful purposes," their term for productive economic use, gives the white settler a right to the land (Bundy, 2014a, n.p.).

However, though land was central to the MNWR occupation, media and academic coverage has instead largely focused on matters other than land. ${ }^{2}$ This, despite the fact that the leaders of the occupiers identified land as the central reason for their actions. ${ }^{3}$ That is, although the occupation was ostensibly in support of the two ranchers in their legal troubles with the federal government, the core issue at stake for the occupation leaders at MNWR was ownership and control of public lands. When the occupation leaders listed their grievances with the government, their primary complaint was the government's ownership of these lands, and their intent was to assist the "people from Harney County. in taking back their land and resources" (Bundy, 2016, n.p.). The primary leaders, brothers Ammon and Ryan Bundy, have a long family history of conflict with the federal government about public land use. The Bundys articulated with public lands a wide range of grievances against the government familiar to any recent example of American antigovernment sentiment and conservative complaint: arguments about federal overreach, the Constitution, and the rights of "the people" all circulated in the Bundys' statements about the occupation. Land was, for the Bundys, the cornerstone of their grievances with the federal government and that which spurred their anti-government rhetorics and actions. The roots of the Bundys' anti-government complaint were grounded in white male settler understandings of land, which in turn formed the basis of their actions.

In this essay I argue that the Bundys' claims about land help us further understand the rhetorical operation of settler colonialism. Specifically, I contend that a fundamental part of the settler colonial project--the remaking of land into property--can be better understood by examining what the Bundys say about land. Land is the ultimate pursuit of settler colonialism, that which is "most valuable, contested, required" (Tuck and Yang, 2012, p. 5). In the pursuit of land, land is recast into property, which makes land "ahistorical in order to hack away the narratives that invoke prior claims" (Tuck and McKenzie, 2015, p. 64). By remaking land, settlers create for themselves new claims to the land that displace Indigenous peoples and the meanings the land has for those people. Put differently, settler narratives make new histories for those lands, which allow them to have a rightful claim to the

\footnotetext{
${ }^{2}$ For example, see: Blumm and Jamin (2016), Brown (2016), Dare and Fletcher (2019), Fantz et al. (2016), Gallaher (2016), Glionna (2016), Inwood and Bonds (2017), and Irons (2018), among others.

${ }^{3}$ The exception here is legal scholarship, which has typically focused on refuting the occupiers' faulty legal claims about public land law.
} 
land. For many Indigenous peoples, land comprises complex relationships, and is interwoven with identity, knowledge, stories, and origin; land is a central part of the ways that these people know and think about themselves and the world around them (Battiste and James, 2008; Endres, 2012; Tuck and McKenzie, 2015; Tsosie, 2018). The logic behind remaking land is based in white settler understandings of land as property; property is something to own, and which is rhetorically constructed through words and actions. I hold that the remaking of land needs further complication, because the process of remaking land does not stop at property. Rather, land is continually recast and remade. The entire reason that settler colonialism remakes land is that ownership and control of land is a mode of power; settler colonialism says, control the land, control everything else. The Bundys recognize this, clearly connecting land to power, arguing that there is a "direct correlation to land and resources with power and wealth" (Bundy, 2014a, n.p.). The family succinctly relates the entire logic of settler colonialism; land is of utmost importance, because land is power. Land becomes a mode of power in part through rhetorical processes.

My essay proceeds in four parts. First, I give context and background on the Bundys and their involvement at MNWR. Second, I outline some of the scholarship on settler colonialism and its fundamental assumptions about land, highlighting three key insights: first, settler colonialism remakes land into property through articulations with ownership rights, sovereignty, and economic development; second, white supremacy is deeply implicated in settler colonialism's understanding of land as property; third and finally, white settler ownership of property relies on the symbolic and material removal of Indigenous peoples from the land. Here also I discuss the inherent entanglement of white masculinity within settler logics. Third, I theorize the concept of land and the significance of land's changing meanings. Finally, I use the three insights about settler colonialism as a framework to analyze the Bundys' claims about land. Following insight number one, I examine the Bundys' arguments about the constitutionality of federal land ownership. Then, I examine how the Bundys define land ownership as a mark of race. Finally, I examine two ways that the Bundys' arguments about land further the erasure of Indigenous peoples, which is a central goal of settler colonialism. Throughout my analysis of the Bundys' rhetorics, I consider how "power" is pervasive to the Constitution, race, and Native erasure.

\section{THE BUNDYS' TROUBLE WITH THE GOVERNMENT: FROM BUNKERVILLE, NEVADA TO BURNS, OREGON}

The Bundy family's long history of confrontation with the federal government can be traced back at least twenty-three years before the MNWR occupation when the Bureau of Land Management (BLM) modified Cliven Bundy's grazing permit on certain tracts of land in 1993. These modifications were intended to reduce the impacts of his herd on the land and the habitat of the endangered desert tortoise. Cliven (father of Ryan and Ammon) refused to comply with the new guidelines, instead turning out "more than nine hundred animals onto the allotment-almost nine times the number stipulated by his permit" (Ketcham, 2015, n.p.). Ketcham (2015), writing for Harper's, describes what happened next over the following years:

In 1994, the agency [BLM] ordered, with the decorum of administrative process, that Bundy remove the cows. One of his sons tore up the notification in front of the BLM officers who delivered it to the ranch. Bundy then attempted, absurdly, to pay his grazing fees to Clark County, which could not accept the money, since it had no jurisdiction over federal land. In 1995, the BLM again ordered Bundy to remove his cattle. Bundy again said he would not, and the BLM again delayed further action. The courts weighed in. The Department of Justice filed a lawsuit in the U.S. District Court for Nevada, which in 1998 found in favor of the government, a decision upheld by a federal appellate court a year later (Ketcham, 2015, n.p.).

After losing twice in court, Cliven continued ignoring the fines and fees he was steadily accumulating (Skillen, 2020, p. 15). During the following years, and as the family bolstered their support among like-minded ranchers, anti-government provocateurs, far-right organizations, and the growing conservative media, the Bundy cattle grazed unhampered (Ketcham, 2015; Skillen, 2020). Then, in 2008, the Department of the Interior (DOI) cancelled Cliven's permit. Cliven ignored the cancellation and his cattle continued grazing on public lands for another 6 years, while he ignored more orders along the way. Finally, in April 2014, twenty-one years after the initial permit modification, the BLM attempted to remove Cliven's herd, intending to auction the cattle off to recoup some of the $\$ 1$ million Bundy owed in unpaid fines and fees. In response, "hundreds of protestors from around the nation" flocked to the Bundy ranch near Bunkerville, Nevada, including heavily armed, self-described militia members. After a tense standoff that lasted about a month, the BLM backed off, citing safety concerns (Lopez, 2016, n.p.). As of the time of this writing, Cliven's cattle still roam public lands in Nevada, and his grazing fees remain unpaid (Yachnin, 2021, n.p.). ${ }^{4}$

In the almost 2 years between the standoff at the family ranch and the MNWR occupation, the Bundys seemed mostly content to write posts for the family blog calling for greater control of the land and resources by private citizens. The family attempted to get a bill passed by the Nevada legislature that would have made it "possible for the people to clearly claim their rights to the resources in Nevada," but this effort quickly failed (Bundy,

${ }^{4}$ Whiteness surely gave the Bundys and their supporters a great deal of privilege in this standoff, as it did at Malheur. A regularly cited example of the differences between white and Indigenous protests is Standing Rock. Water Protectors at Standing Rock faced a much different response from the government and law enforcement. For analyses of how protestors at Standing Rock were treated, see: Christiansen (2021), Johnson (2019), Welch and Scott (2018/2019). 
2015 a, n.p.). Things changed in late 2015, however, when the case of Dwight and Steven Hammond first appeared on the Bundy blog on November 3. In the 2 months between the first Hammond-related post and the occupation of MNWR on January 2, the family dedicated sixteen posts related to the father-and-son Oregon ranchers. The Bundys claimed their subsequent occupation of MNWR was in support of the Hammonds; though, after the occupation began, the focus on the blog quickly shifts from the Hammonds to the Bundys' fight with the government and subsequent legal issues. Indeed, only one mention of the Hammond family is made on the blog after January 6, 2016. Even in this final post, the focus is largely on the Bundys' own plight. As this archival archaeology shows, the family's focus was never really the Hammonds, who seem to have largely been a convenient cause to further the Bundys' own agenda. ${ }^{5}$

The Bundys and their followers arrived in Burns, where a local protest supporting the Hammonds was already planned, on January 2, 2016. Approximately three hundred people marched in the protest to show their support for the ranchers. Dwight and Steven Hammond had been prosecuted by the federal government over two cases of arson, in 2001 and 2006, initially receiving abbreviated sentences in 2012. The first fire was allegedly set to cover up an illegal deer hunt, while the second was lit as a back-burn against a lightning-caused fire in order to protect their cattle and land (Wiles, 2016). After appeal, the original sentences the Hammonds received were deemed to be below the minimum required by law and, in October 2015, Dwight and Steven were ordered to finish the remainder of their 5-year sentences. Donald Trump eventually commuted their sentences in July 2018 (Chappell, 2018).

After participating in the protest in Burns on January 2, Ryan and Ammon Bundy, with a group of about thirty supporters, took over the then-closed MNWR headquarters later that day. The refuge headquarters was occupied for a little over a month, until February 11. Between the start of the occupation and when the final occupier eventually surrendered to law enforcement fortyone days later, both Bundy brothers and nearly all of their supporters were arrested, and one man, Robert "Lavoy" Finicum, was shot dead resisting arrest. Though the Bundys and their followers claimed to be helping the citizens of Harney County (where Malheur and Burns are located), most locals did not want their help. Not only were most of the residents of Harney County opposed to the Bundys' takeover of the refuge, none of the occupation's leaders were locals, or even from Oregon

\footnotetext{
${ }^{5} \mathrm{My}$ primary texts for this analysis are ten posts from the Bundy Ranch Blog, where the Bundy family posted regular updates about their legal fights and confrontations with federal officials from 2012 through 2017. The posts I examine range from 2012 to during the 2016 MNWR standoff, but are primarily from 2014 to 2015 . Supplementing these blog posts are quotes from the family in various news outlets, primarily from interviews and press conferences conducted during the MNWR standoff. I chose these particular entries and quotes after reading through the majority of the family's blog posts and a wide range of news stories, selecting those that best represent the Bundys' views on public lands, the federal government, and ownership. I then read these texts through a lens informed by scholarship on settler colonialism to conduct my analysis.
}

(Walker, 2016). Indeed, few of those who occupied the refuge actually lived in Oregon; most were from elsewhere in the West, including Idaho, Utah, Arizona, and Montana. Further, the Hammonds--who the Bundys claimed to be supporting and whose plight supposedly sparked their actions--did not even want their help (Fantz et al., 2016; Wiles, 2016). Finally, the Bundys and their followers did not share the same motives as locals. As Peter Walker writes, "It is important to understand that for virtually all Harney County residents, the rally in Burns on January 2 was about the sentencing of the Hammonds--not about opposing federal ownership of land" (2016, n.p.). For the Bundys, however, federal land ownership was very much the focus.

I contend that the Bundys' rhetorics about public lands, MNWR, and the federal government can help us further understand the rhetorical operation of settler colonialism. The Bundys demonstrate a key tenet of settler colonialism: the rhetorical transformation of land (Tuck and McKenzie, 2015). As a particular kind of colonialism, settler colonialism is characterized by outsiders coming to land previously inhabited by Indigenous peoples, claiming it as their own, and removing those people from the land. The case of the Bundys and MNWR demonstrates that settler colonialism works rhetorically, in part, through the changing meanings of land. That is, when the Bundys occupied the refuge and talked about land, they brought new associations and topics to the land in Harney County. When the Bundys changed the land's meanings, they affected the land's transformation. A key feature of the Bundys' enactment of settler logics, I suggest, was their aggressive display of white masculinity. In the next section I describe settler colonialism and how the transformation of land in the Bundys' rhetorics further settler colonialism's goals.

\section{SETTLER COLONIALISM}

I am a non-Native man living and writing in Kansas, a region that is today home to the tribal reservations of the Iowa, Kickapoo, Potawatomi, and Sac and Fox nations, and is the ancestral homelands the Arapaho, Cheyenne, Comanche, Kansa, Kiowa, Osage, Pawnee, Oceti Sakowin, and Wichita tribes and nations. My relationship to this land and the subjects of land ownership, private property, and settler colonialism has shaped my identity in many ways--I am the grandson of third generation Kansas farmers, and today live nearby that family farm. Throughout my childhood and early adulthood, I grew up thinking of the Kansas farm as the family home, my ancestral homeland. The colonial history of this land was never part of my education, and my relationship to the land existed without knowledge of the history of colonial violence. Making such histories unknown is a key method through which settler colonialism operates. As such, there is also a direct link between this Kansas land and the land discussed in my essay. What is today private farmland in Kansas was, not too long ago, public land. This land just followed the settler logics of becoming private property more fully than the lands that I discuss in this paper. As a private farm, my family's home and my relationship to it are the desired end of the Bundys' 
arguments: private property owned by white settlers. Part of my reasons for the subjects I research today is informed by my relationship to land as a settler, so that we can better understand how land and discourses about land are used to continue the logics, practices, and violence of settler colonialism, and better understand our own relationships to land.

Three key insights about settler colonialism are particularly helpful in demonstrating how the Bundys contribute to the rhetorical operation of settler colonialism. In the case of the Bundys, white masculine ideals of control are a key feature of their settler colonial rhetorical strategies. First, settler colonialism remakes land into property through articulations with ownership rights, sovereignty, and economic development. Second, white supremacy is deeply implicated in settler colonialism's understanding of land as property. Especially in the context of the early United States, human relationship to land was a mark of race: Indigenous, Black, and white peoples have all been racialized in different ways according to their relationship with land. Where Native Americans were marked by having their lands stolen from them, Black people were marked by having been stolen from their lands; whites, having affected both thefts, became owners of newly racialized property (Wolfe, 2006; Liboiron, 2021). As such, there is a perceived right of white settlers to land and property which is "a cornerstone for the ongoing production of white supremacy and white racial identities in the US" (Inwood and Bonds, 2017, p. 254). Third and finally, white settler ownership of property relies on the symbolic and material removal of Indigenous peoples from the land. Taylor (2016) notes that "the use of concepts and terminology such as frontier and pioneer not only erases the presence of indigenous peoples but also establishes the settler as the "first" people to see, do, or experience whatever is being described on "empty" land. It grants settlers ownership and control of land and other resources and gives primacy to their claims" (Taylor, 2016, p. 21, emphasis in original). Ultimately, the transformation of land into property owned by white settlers depends on the erasure of Indigenous peoples.

Settler colonial logics are firmly fixed in the broader American imagination. For example, in April 2021 former US senator and commentator for CNN Rick Santorum made headlines for claiming that "there isn't much Native American culture in American culture" (Fitzsimmons, 2021, n.p.). ${ }^{6}$ Nick Estes (2021), assistant professor at the University of New Mexico and a citizen of the Lower Brule Sioux Tribe, wrote for The Guardian that Santorum:

repeated a widely held myth of US exceptionalism. "We came here and created a blank slate, we birthed a nation from nothing," the former US senator and CNN commentator told the rightwing Young America's Foundation's summit. "It was born of the people who came here." His "we" doesn't include Indigenous people who were already here or African

${ }^{6}$ Santorum was dismissed from CNN shortly after making these comments (Stelte, 2021). people who were brought in chains. And that "blank slate" required the violent pillaging of two continents--Africa and North America. If the United States was "birthed from nothing", then the land and enslaved labor that made the wealth of this nation must have fallen from the sky--because it surely didn't come from Europe (Estes, 2021, n.p.).

Further, Estes wrote, "The erasure of Native histories and peoples--which existed long before and despite a white supremacist empire--is a founding principle of the United States" (2021, n.p.). The casual racism of Santorum's remark exemplifies the manner in which Indigenous peoples have been strategically erased in the collective story we tell about the United States, a story in which public lands play a prominent role. The history of the public lands is a history of Native American erasure, where Indigenous populations were removed from land so that (predominantly white) settlers could occupy them and, later, so that the US government could preserve them in the form of National Parks, National Forests, and National Wildlife Refuges.

A central feature of the Malheur occupation, and the settler logics influencing the occupiers, was an aggressive display of white masculinity. This display was revealed in multiple ways, from the gender roles the occupiers adopted, to the display of guns from various people at the refuge, to assumptions the occupiers held about public lands and property. The aggressive masculinity on display by the Bundys at Malheur reminds us that public lands are coded as the property of white (male) settlers, and reveals the paradox of white masculine victimhood (Johnson, 2017). That is, the need to control land arises from a feeling of helplessness, which can only be assuaged through violent reminders of white male dominance. Further, the Bundys' aggressive masculinity--enacted through the display of firearms, gender roles, and arguments about property--is indicative of the settler colonial narratives through which the Bundys understand public lands. That is, the Bundys' display of white masculinity shows us that they see public lands through the logics of settler colonialism, because the white male settler asserts his dominance, in part, through controlling the land. For the Bundys, land is the basis on which their control rests.

As Irons (2018) notes, the occupiers adopted conventional gender roles during their time at Malheur. While the majority of the occupiers were men, there were women at the refuge. With the exception of Shawna Cox, the only woman arrested with the other occupiers, most of the women at Malheur were tasked with the daily work of keeping the refuge running, such as "cooking, cleaning, and organizing supplies" (Irons, 2018, p. 488). The men, meanwhile, stood guard with guns drawn. The women's role at Malheur was a crucial part of this display of masculinity and, as "women often do within patriarchal systems, these women contributed to the image of the male occupiers as masculine, dominating figures by reflecting a magnified image of their masculinity back at them. They emphasized that the men were "protecting" the women, further perpetuating the image of these men as providers and guardians of their community" (Irons, 2018 , p. 517). The men were portrayed as the occupation's 
leaders, relying on the women to keep daily life functioning while they, in their eyes, defended the land and the people's rights. The domination of men over land and women is a central feature of settler colonialism, with men portrayed as the heroes protecting their women and taming the land. ${ }^{7}$

The Bundys' colonial desire to control the land also reveals the paradox of white masculine victimhood. Arising out of a feeling of uncertainty, victimhood is a state of perceived slight. As Johnson (2017) writes, "claims of White, masculine victimhood encourage objectively well-off members of society to interpret the presence of difference and uncertainty as threatening the subject with unjust marginalization" (2017, p. 231). By portraying themselves as victims, the Bundys were able to disavow how every aspect of society is structured by white masculinity (Kelly and Neville-Shepard, 2020). In other words, the Bundys clearly feel as though they are on the outskirts of society and feel they have no control over their lives. As both Irons (2018) and Shaw (2016) have written, the aggressive, hypermasculine posturing of the Malheur occupiers signals a feeling of powerlessness, or that these men felt helpless against the federal government's regulations of the majority of land in the west and, by extension, control over their lives.

The display of guns is yet another way in which the occupiers featured their aggressive masculinity, and signals their feelings of precarity. Neville-Shepard and Kelly (2020) write the "public display of guns is tethered to a history of White supremacy and racist violence" (2020, p. 467). Further, Neville-Shepard and Kelly argue, carrying guns is coded as a specifically white male practice, one which can help "aggrieved White men contrive an image of an emasculating and oppressive state that can only be countered by the militant reassertion of White masculine sovereignty over public space" (2020, p. 468). Through the open carrying of firearms, the Bundys and their followers asserted their dominance over the government, the land, and the Burns Paiute. Put differently, the Bundys' "White masculine sovereignty" was affirmed over their own lives, their families, the Burns Paiute, and the government through "taking back" the public lands at Malheur. The Bundys remind us that it is the privilege of white men to treat property as they wish without much consequence, even when the property is not theirs. MNWR was not the Bundys' in at least two ways, being federal property and also the homelands of the Burns Paiute. However, the Bundys see public lands through the logics of settler colonialism, which tell us that land rightfully belongs to white male settlers.

The aggressive display of white masculinity at MNWR reminds us of the privilege white men have; to be able to violently occupy federal property for more than a month, with little to no consequence, is a mark of inherent privilege. The Bundys' display of masculinity is also a reminder of the logics of settler colonialism. As the Bundys understand public lands, they are rightfully the property of white male settlers. As I will discuss

${ }^{7}$ A key way in which settler colonial narratives have become central to the (white) US collective identity is through the frontier myth. For a discussion of how the frontier myth is gendered and supports white male dominance, see: Rushing (1989), Kelly and Neville-Shepard (2020). further in my analysis, the Bundys argue that the federal government cannot own public lands, and that they should be privatized. Further, the Bundys are untroubled by the claims of Native Americans to the land; remember, as Ryan said, Native Americans lost their claim. Presumably, the Burns Paiute do not have a strong claim to the land because they had it taken from them. For settler colonialism, land is the ultimate goal and, for the Bundys, control of land is the ultimate masculine ideal.

The Bundys' arguments are thus premised on the assumption that public lands belong to (white, male) individual property owners; as the family once wrote, "the legal and rightful control of the land belongs to the local people" (Bundy, 2014b, n.p.). Or, as Ryan Bundy put it in an interview during the MNWR occupation, the occupiers recognized that "the Native Americans had the claim to the land, but they lost that claim. There are things to learn from the cultures of the past, but the current culture is the most important" (qtd. in Keeler, 2017, p. 3). Keeler (2017) interprets the "current culture" mentioned by Ryan as "one epitomized by cowboys and ranching," while noting that this only "comprises a tiny minority of Americans today" (2017, pp. $3-4)$. Keeler pinpoints the Bundy family aesthetic--how they present themselves, with ever-present western wear such as cowboy hats, buttoned shirts, blue jeans, and boots--and notes that neither Ryan nor Ammon Bundy are working ranchers. ${ }^{8}$ Indeed, Keeler continues: "the Bundy's mischaracterization rules much of the public's imagination to this day" $(2017$, p. 4). Understandably, the characterization of the Bundy brothers as ranchers is most likely attributable to the 2014 standoff at the family ranch and the fact that patriarch Cliven is actually a working rancher. Extending Keeler's argument here, I believe that Ryan's statement about culture, Native Americans, and claims to the land is an indication that the logics of settler colonialism--and thus Native American erasure--are fixed firmly in the family's views of land. Ryan's words are not only as an attempt to, as it were, play cowboy. Instead, Ryan spoke from deeply-held, foundational beliefs about who has access to and rightful ownership of land. Before examining what the Bundys say about public lands, we need a stronger understanding of land itself and the rhetorical stakes of the shifting meanings of land.

\section{LAND}

Land was at stake in the MNWR occupation. When the Bundys talked about the motivations and reasons behind their actions, they discussed a wide-ranging list of issues and people: government and the Constitution, ranching and ranchers, rights and freedoms, MNWR and wildlife, the economy and resource production, and "the People" and Native Americans all

${ }^{8}$ It appears that only four of the approximately thirty occupiers actually worked as ranchers and, of those four, only one--Lavoy Finicum--actually stayed at the refuge and fully participated in the takeover. The other three appear to have been visitors to the refuge, and their roles in the occupation are unclear (AntiDefamation League, 2021; The Oregonian/Oregon Live, 2016). 
circulated through the family's rhetorics. Tying these various issues together was the land itself. When the family talked about government, their primary complaint of governmental oppression was federal control of the land; when they talked about the Constitution, the only clauses that mattered were the ones that address the federal government's ownership of that same land. When they discussed the economy, the Bundys made it clear that land is the basis of any economic activity; when they talked about wildlife and the refuge, they claimed that it was the interactions of humans and livestock with the land of the Harney Basin that attracted the wild animals. When the family discussed freedoms, rights, and "the People," land was said to be the foundation of the Peoples' rights and freedoms. No matter the topic, for the Bundys, land was at the center of the conversation.

Given the importance of land to the Bundys, surprisingly little attention has been given to the land in the scholarship on the takeover of the refuge. When journalists and academics do attend to the land and the Bundys' arguments about it, land often remains in the background, a seemingly minor matter, adjacent to other topics of discussion. For example, in their recent essay on the Bundys and MNWR, Dare and Fletcher promise to focus "on the interdependence among the land, nonhuman animals, and humans," examining a "land-use controversy from a "birding" perspective [which] helps to open up a view of human-animal-land interconnectedness" (2019, pp. 413 \& 414). However, the land seems to quickly fall out of their analysis, the essay focusing firmly on the human and non-human relationships bound up in the land-use dispute, without much discussion of the land itself. Dare and Fletcher's essay is not alone in this regard. ${ }^{9}$ Even in the scholarship concerning MNWR and the Bundys in law and geography--two disciplines seemingly well-positioned to talk about land--the land is buried under a pile of other issues. ${ }^{10}$ Typically speaking, scholarship on the Bundys and MNWR tends to assume that land is a given, physical object that, as a concept, remains stable and unchanging. That is, this view assumes that the land is the same for the Bundys as it is for the ranchers of Harney County, for the Burns Paiute Tribe, for the federal government, for scholars, or for journalists. Contrary to this tendency, I hold that land is not a stable concept, and is instead always changing from speaker to speaker. Further, I hold that understanding land in this way is an essential part of understanding the Bundys' anti-government actions and rhetorics, as well as understanding the rhetorical operation of settler colonialism.

Land is often portrayed as a decidedly material concept, physical, and solid concept, composed of soil, rocks, minerals, geological formations. As a material object, land remains stable and permanent, unquestioned, and without meaning. For instance, Clark (2004), in his study of rhetorical landscapes,

\footnotetext{
9See also: Bonds and Inwood (2016), Ladino (2019), LeMenager and Weisiger (2019), Morgan (2019), and Welch and Scott (2018/2019).

${ }^{10}$ For example: Blumm and Fraser (2017), Blumm and Jamin (2016), Eisenberg (2017a), Eisenberg (2017b), Gallaher (2016), Ingalls et al. (2019), Inwood and Bonds (2017), Irons (2018), Zellmer (2019).
}

tourism, and national parks, argues that there is a difference between "land" and "landscape." Here's Clark:

Landscape is not the same as land. Land is material, a particular object, while landscape is conceptual. When people act as tourists, they leave the land where they make their home to encounter landscapes. Land becomes landscape when it is assigned the role of symbol, and as symbol it functions rhetorically (2004, p.9, emphasis in original).

Clark ties land to territory, the mere material stuff upon which we stand. Land, in and of itself, has no meaning for Clark other than its solidity, while landscape, imbued with all the power of symbolism, is tied to identity (2004, p. 71$)$. The essential point is that Clark assumes that "land" is a homogenous concept without symbolism and, thus, without meaning. That is, land does not change; it is permanent. Once land acquires meaning, however, it becomes something else, something different altogether from that which it was previously; it is no longer land. Put differently, landscape is an idea, a concept, while land is the physical, material object upon which we stand. Significantly, Clark's understanding of land is consistent with a colonial worldview, one which assumes that land is "common, universal, and everywhere, even with great variation" (Liboiron, 2021, pp. 6-7, fn. 19). In this understanding, land exists everywhere, the same for everybody. Even if what land looks like changes, the concept of land remains the same.

As Druschke (2013) points out in her work on a watershed in Iowa, Clark regards "the symbolic as the sole territory of the rhetorical," and that "the landscape is strictly symbolic terrain" (2013, p. 93). According to Clark, writes Druschke, the "rhetoricity of a given landscape exists only in its symbolic content; the material land drops away once that land is imbued with symbolic meaning" (2013, p. 93). Druschke complicates Clark's understanding of land as only material, and without rhetoricity. Significantly, Druschke complicates Clark's understanding of land by describing its impermanence, or how land--in the topos of watershed--changes (2013). In their essay on identity and Maine's North Woods, Hutchins and Stormer (2013) write that the impermanence of land is often revealed through conflict and disruption. Using articulation theory, Hutchins and Stormer write that land is "an element within a system of practices related to it," entangled with discourse, identity, and practices that, together, construct place and identity (2013, pp. $27 \& 35$ ). Building from this study, I hold that land is a conjunction, a combination of elements that, in the case of the Bundys, articulates ideas about property, rights and freedoms, government, the economy, and power together. Put differently, land is that which brings together various discourses and material practices. As new discourses and practices are articulated with land, land's meanings change. When the Bundys occupied the refuge, public lands in Harney County came to mean something different than they had for the county's residents and the Burns Paiute Tribe prior to January 2 , 2016. The changing meaning of land is significant because, as Hutchins and Stormer argue, meaning "is not the semantic value 
of a sign," but rather "the significance established through conjunctions" (2013, p. 27). That is, when "land" became associated with power, governmental oppression, the Constitution, and rights and freedoms through the Bundys, this new combination of elements changed what the land was in this instance. The land's changing meanings allowed the Bundys to insert new arguments about the land as a consequence of these new associations. The concept of "land" is not permanent and stable, the same for the Bundys in their takeover of MNWF as it did for the federal government, the Burns Paiute Tribe, and the citizens of Harney County. Examining in closer detail what the Bundys and leaders of the Burns Paiute Tribe say about the land of MNWR bring these differences into sharper focus.

\section{COMPETING MEANINGS OF LAND: THE BURNS PAIUTE TRIBE, THE BUNDYS, AND SETTLER COLONIALISM}

For the Burns Paiute Tribe, the land at Malheur is associated with their history and of their tribe having existed in this area for thousands of years. As Charlotte Roderique--former Chairwoman of the Tribe--says, the tribe was "here first" before "any of these ranchers" (qtd. in Sam, 2018, p. 47). The land also signals a resilience to colonialism and a perseverance to survive in this place; the Native people who live in the region today are the descendants of those who lived there far before colonization and removal in the nineteenth century, and who then came back to the region at a later time. In their calls to end the occupation, tribal leaders indicated that they saw the Bundys as perpetuating the same sort of colonial politics that saw their ancestors originally removed from the region. Jarvis Kennedy, a member of the tribal council, told reporters that he thought the occupiers were "just a bunch of bullies and little criminals coming in here and trying to push us around over here and occupy our aboriginal territories out there where our ancestors are buried. It gets tiring. It's the same battles that my ancestors had. And now it's just a bunch of different cavalry wearing a bunch of different coats" (qtd. in Sidner, 2016, n.p.). In other words, tribal leaders understood the Bundys' occupation as yet another chapter in a long history of white outsiders taking their lands. Roderique, speaking about the occupiers, said "they are desecrating one of our sacred sites. They are endangering our children and the safety of our community." (qtd. in Sam, 2018, p. 44).

The Bundys' primarily understand land as a resource, most valuable for what it gives humans to use, which fits squarely within settler colonial logics. This definition values the land for its extractable potential and what uses humans can put the land toward, what the family call the land's "useful purposes" (2012a, n.p.). There are two important factors in this definition of land. First, land is something that can be taken and bent to the will of human users. Accordingly, land can also be "conquered," taken over and controlled by those who put land to useful ends (2014a, n.p.). Second, land can be improved to the benefit of humans. Listed improvements were water resources for wildlife and livestock, habitat for livestock and wildlife, and improving the forage for livestock while also reducing the fuel load in order to better control fire (2012b). All of these improvements provide human users with more resources to harvest and use (2012a). Significantly, however, the Bundys argue that it is only private owners who improve the land. In the family's telling, the government restricts the ability of land users to productively use the land and extract its resources (2015d). Further, government control of land has gendered implications for the Bundys. As Irons (2018) argues, government control of the land threatens the Bundys' "livelihood and ability to serve as providers within their families. As their role as provider is central to their familial, gendered hierarchy, control over the land is a threat to these men's control over their families" (2018, p. 508). By threatening the hierarchy of family and the men's ability to provide, the government threatens the men's role of authority within their family structure (Irons, 2018). For the Bundys, land functions as both a provider of resources for human use and as a source of masculine authority.

Land's meanings are tenuous, never stable or permanent. Importantly, the changing meanings of land have implications for our understandings of settler colonialism. Settler colonialism's description of land in terms of resource and productivity objectifies land, stripping it of any meaning and agency outside colonial knowledge systems. Settler colonialism is a violent disruption of human relationships with the environment or, as Whyte (2018) argues, "ecological domination" (2018, p. 125). Settler colonialism accomplishes disruption and domination through remaking land and human relationships to land; Tuck and Yang (2012) write, the settler:

is making a new "home" and that home is rooted in a homesteading worldview where the wild land and wild people were made for his benefit. He can only make his identity as a settler by making the land produce, and produce excessively, because "civilization" is defined as production in excess of the "natural" world (i.e. in excess of the sustainable production already present in the Indigenous world) (2012, p. 6).

Settler colonialism's remaking of land recasts land through new knowledge systems. Making land into property undergirds "a normalized white supremacy” (Inwood and Bonds, 2017, p. 256). That is, as land becomes property, settler colonialism props up knowledge systems that constitute "whiteness and property are cornerstones of settler traditions of place in that they are reflective of past histories of genocide, Native land displacement, and enslaved labor underpinning contemporary social relations and materialities" (Inwood and Bonds, 2017, p. 256).

With the Bundys' at Malheur, the family brought to Malheur new entanglements which ignored the land's history, both the Indigenous history and history of colonial settlement, and gave new meanings to the land. In terms of the land's Indigenous history, the Burns Paiute frequently reminded the press that they were the land's original inhabitants, and that their tribe's history with the land was fraught with colonial violence (Peacher, 2016; Sidner, 2016; Sam, 2018). The Bundys did not accurately portray the colonial history of the land either, clearly knowing and caring 
little about cattle ranching in the region, the creation of MNWR, and the relationship between locals (both settler and Indigenous) with the federal government (Peacher, 2016; Robbins, 2016). In short, the Bundys brought to MNWR new articulations of land with government, history, and rights and freedoms that gave the land new meanings, meanings which enabled them to forward an argument of this land as rightfully the property of white settlers. ${ }^{11}$

With the instability of land informing my analysis, I examine what the Bundys associate with land--what they entangle with it, link to it, and what they bring to attention when they talk about land. Land provides the family numerous rhetorical resources and is thus fundamentally entangled with a broad range of cultural-political concerns. For the Bundys, the land itself oscillates between economic resource, the foundation of personal rights, a symbol and site of governmental oppression, a mode of power, and the basis of a theory of constitutional interpretation. Land is ever-changing for the family, every bit as much tied to government and freedoms as it is a natural resource. This is why the family can discuss land as the key to any economic activity and then, in the same breath, tie land to a theory of governmental power and constitutional interpretation. The Bundys' takeover of MNWR demonstrates the rhetorical power of land, that land has no inherent, singular meaning and is instead always in flux, defined as much by the cultural and political needs of speakers as by the material composition of sand, soil, rocks, and geographic coordinates.

\section{THE BUNDYS AND LAND: THREE CLAIMS}

Though land is ever-changing for the Bundys, there are constants in the ways that they talk about and entangle with land. In this section, I analyze the Bundys' claims about public lands, using the insights detailed above about settler colonialism and land. I argue that the Bundys' further the goals of settler colonialism by redefining the land's meanings. I examine three particular entanglements common to the family's discourse: the Constitution, race, and Native erasure. First, I examine the Bundys' arguments about the Constitution. Here, the family argues that the Constitution gives the people power over the federal government. Second, I examine how the family racializes relationship to land, or how white settlers come to be the proper owners of land. Power here is related to who are the beneficiaries of land and its resources. Third, I examine the ways in which the Bundys' arguments further settler colonial strategies of Native erasure through what they say about public lands history and land use. Here, power is related to land through definitions of land and history. Throughout, power is ingredient to these three entanglements. The entire reason that settler colonialism

\footnotetext{
${ }^{11}$ While my paper is focused on the meanings given to land by humans, it is important to note that settler colonial notions of land are particularly restrictive when it comes to the land's agency. That is, settler understandings of land primarily conceive of land as a permanent and stable object without agency. See Dare and Fletcher (2019) essay for an analysis of the agencies of land and nonhumans, and the inseparability of humans with those agencies.
}

remakes land into that which the settler can claim is because land is a mode of power; control the land, control everything else.

\section{CONSTITUTION}

The first way that the Bundys further the rhetorical operation of settler colonialism through their arguments about land is by defining proper land ownership vis-à-vis their interpretation of the Constitution. The Bundys' claims about constitutional limits on federal land ownership should be understood as support for their larger argument about the privatization of public lands. The primary meaning associated with land here is "property," specifically private property, not government or public property. According to the family, the federal government is strictly limited to owning only small amounts of land in very specific circumstances. The family strategically reads the Constitution to support their claims to private property, largely relying on two specific constitutional clauses: the Enclave Clause and the Property Clause, as well as a method of interpretation called "textualism." Textualism is the belief that the Constitution can be understood by "reading the text, without any detailed knowledge of the history and context of its formulation and without taking into account how the Constitution has been authoritatively interpreted by federal courts over the past two centuries" (Smith, 2016, p. 1). Using this interpretative method, the Bundys argue that because the federal government is constitutionally limited in its ability to own land, the vast majority of federal property should be owned by private individuals. The assumption that land should be private property follows the long tradition in the United States of justifying the seizure of land from Indigenous peoples in the name of white male settler property rights (Taylor, 2016). In this context, land's meaning as private property is a fundamental aspect of settler colonialism. The Bundys' arguments about the Constitution, federal land ownership, and private property are an extension of such settler colonial logics.

The family's claims about power are, by necessity, tightly tied to their arguments about the Constitution, and are premised on the assumption that land should be understood as private property. As the Bundys use the term, "power" signals political control; most often, the family presents "power" in terms of a binary, meaning control of either the population or the government. Crucially, control of both population and government depends on control of the land. When the people control the land, they control the government; when the government controls the land, it controls the people. The family argues that the federal government is expressly prohibited from owning too much land because the Constitution is designed to limit the government's powers by strictly delineating what lands the government could control (Bundy, 2014a). The original plan of land disposal, the Bundys claim, keeps the land and power "safe" with the local people (Bundy, 2014a, n.p.).

Rhetorically, situating federal public lands as instead private property enables the family to define the land, its uses, and who gets to own land. The belief that public lands should be turned 
into private property falls within an ideology often called "land transfer." The Bundys argue that the original intent of the federal government was to "quickly dispose the land and resources to the local people, where it is most safe" (Bundy, 2014a, n.p.). Disposal of land to private individuals was indeed an early federal public lands policy, but one which the government moved away from in the late nineteenth century. The family's emphasis on disposal is more than a preference for a previous policy, however; according to the Bundys, federal ownership of public lands goes against the very foundations of individual rights, freedoms, and liberties, as well as the proper form of government itself. In one blog post, the family writes, "the legal and rightful control of the land belongs to the local people," and calls on state and local governments to "take control of the land. [and] dispose of the land to the people" (Bundy, 2014b, n.p.). The family argues that federal land leads to a system where "the people that live on or near the land have no say to what happens in their own backyards" and the government does not "protect and uphold the rights of the people" (Bundy, 2014a, n.p.). Further, the family argues that the Founding Fathers intended the land to go to private citizens because this would ensure the proper form of government and governmental power, arguing that the Constitution limits "the powers of government by outlining what lands the federal government can control and by separating the powers they hold. This is called a republic form of government, for the people, by the people"(Bundy, 2014a, n.p.). Put simply, the Bundys argue that the vast majority of land should be owned by private citizens because private property is the guarantor of freedoms liberties, rights, and the proper form of government.

As legal scholars note, the Bundys' interpretation of the Constitution has no support in history or jurisprudence (Blumm and Jamin, 2016; Irons, 2018). Ironically, given their beliefs about textualism as a method, the family actually misreads the text of the document, conveniently ignoring the text to their own ends (Smith, 2016). Specifically, the family argues that the Enclave Clause gives the federal government authority to own land "only ten square-miles from Washington, D.C” (Blumm and Jamin, 2016, p. 814). The Property Clause, according to the family, only allows the federal government to own property with "Territories." In this reading, once a Territory becomes a state, the federal government must "give up the land unless they could take control of it in the narrow circumstances outlined in the Enclave Clause." (Irons, 2018, p. 486). Ryan explained the family's position thus: "the Constitution grants Congress the power to make needful rules and regulations while the land is still a Territory (capital T) and grants Congress the power to dispose of the land." In the Bundys' view, this means that the government has the ability to control the land when it is still in a "Territory," which is supposedly different from a state (Bundy, 2015c, n.p.). This is an important distinction for the family, because once a "Territory" became a state, the federal government lost the ability to own land inside the state, except for very limited circumstances (Bundy, 2015c). However, these arguments have no basis in jurisprudence. Bundy's contention that there is constitutional significance between "Territories" and "territories": was considered and rejected by the Supreme Court 176 years ago in United States v. Gratiot. In fact, Bundy's reasoning echoes Justice Taney's discredited analysis of the Property Clause in Dred Scott-that Congress lacked the authority to establish rules for federal territories in the West that were not part of the Union at the time of the Constitution. Thus, Bundy relies on the most reviled decision in Supreme Court history as the only authority supporting his view (Blumm and Jamin, 2016, p. 815).

The Bundys also ignore the fact that federal ownership and control over MNWR has already been upheld by the Supreme Court (Blumm and Jamin, 2016, p. 816). Additionally, the family either misunderstood, or did not know, the history of cattle ranching, federal land ownership, and cooperation between residents and government in Harney County (Robbins, 2016, p. 574). ${ }^{12}$ In sum, the Bundys' arguments about public lands, the federal government, and the Constitution have all been thoroughly discredited, and shown to be based in faulty understandings of history and law. As these arguments articulate land, however, it is clear that the Bundys understand land through the foundational logics of settler colonialism. The notion of land-as-private property justified the settlement of Indigenous land and gives the Bundys the ability to claim a right to the land. This claim, and the assumptions behind it, will be examined in the next section.

\section{RACIALIZING LAND}

The second way that the Bundys further the rhetorical operation of settler colonialism through their arguments about land is by racializing relationships to land. The primary relationship that I will discuss here is ownership--what the Bundys say about ownership of land, and also the response of the Burns Paiute to the Bundys' arguments. In the Bundys' arguments, ownership of land continues to be a mark of race; whether they admit it or not, land ownership is something that belongs properly to white settlers. Further, land ownership is connected to power in the MNWR occupiers' rhetorics. One of the Bundys' co-conspirators at Malheur, Ryan Payne, succinctly told the New York Times, "the idea is power: land is power" (Johnson and Healy, 2016, n.p.). The idea that land is power can be traced back to the Bundys arguments after their 2014 standoff with the federal

\footnotetext{
${ }^{12}$ For example, Harney County government works to promote active cooperation between public lands users (including ranchers) and the federal government, and provides resources for land users to learn about and become involved with collaborations with the government (see Public Land Issues and Resources. Harney County. https://www.co.harney.or.us/index.php/public-land-issues-andresources). Robbins provides an excellent overview of the history of local and federal cooperation on public lands issues in Harney County. Of particular significance to this essay is how the public was involved in recent planning at MNWR, including "an exhaustive collaborative review and planning exercise. The nearly 5 years' work involved state, local, and tribal governments, individuals, and private nonprofit organizations" (2016, pp. 596-597).
} 
government. In a series of blog posts, the family connected land to control, arguing that "history proves that whoever controls the land and the resources control the people" (Bundy, 2014c, n.p.). The articulation of land with power and control is why the family believes that federal land ownership is so problematic. In their view, Americans' freedoms are at risk when the government controls too much land. As the Bundys argue, freedoms are directly tied to the land, and that the "federal agencies" clearly understand "power and have taken great measures to control the land and resources. Control the land and the resources and you possess the power to manipulate the people and/or oppress them" (Bundy, 2014c, n.p.).

The first key to understanding the Bundys' racialization of land is who the family defines as the owners of Harney County's public lands. In one interview, Ammon Bundy claimed that the "best possible outcome" of the Malheur occupation would be for the ranchers who have been "kicked out of the area" to "come back and reclaim their land." In this scenario, Ammon hoped that the wildlife refuge would "be shut down forever" and the federal government relinquish any claim to the land (Wolf et al., 2016, n.p.). The rightful owners, presumably, were not the Burns Paiute Tribe, on whose ancestral lands MNWR sits, though the Bundys said they supported the Tribe's claims to their ancestral lands at various points (Glionna, 2016). Their actions, however, belied these messages of support, and spoke to the family's fundamental assumption about these lands; that they belong to the white people of Harney County. A far cry from respecting the Tribe's wishes regarding their occupation, the Bundys and their followers "handled and moved" ancient artifacts stored at the refuge and "bulldozed through sacred burial grounds while trying to build a road" (Siegler, 2016, n.p.). Further, Ryan Bundy once argued that the Tribe had "lost" their claim to the land, and that the land now belonged to the "current culture" (Keeler, 2017, p. 3). When the Bundys claimed that they wanted to help the land's rightful owners take back their land, they meant "the people of Harney County who have pre-emptive rights" to the land (Bundy, 2016, n.p.).

The second key to the Bundys' racialization of land ownership is the concept of rights of preemption. According to the Bundys, rights of preemption are what give the citizens of Harney County the legal claim to the land. Preemptive rights are essentially squatters' rights, protection from land speculators for those who live on the land and make "improvements" to it (Gates and Swenson, 1968, p. 68). Preemption, as a logic of colonialism, assumes that land belongs to those who work it, and make productive use of the land. In the Bundys' parlance, land belongs to those who put it toward "useful purposes" (Bundy, 2014 b, n.p.). King (2019) writes this notion of working the land and what counts as a "productive use" descends from the Lockean tradition of property rights and assumes that "Indigenous subjects who do not labor across the land fail to turn the land into property and thus fail to turn themselves into proper human subjects" (2019, p. 23). Land ownership is connected to economic and political self-reliance and, Shelton (2013) notes, in early US history property rights became "a means of thinking about the unalienable rights of humankind" (2013, p. 1). In the settler state, of course, only a particular kind of person gets to own land and, thus, receive the status associated with land ownership. ${ }^{13}$ Whiteness, as the mark of the proper landowner, has long been entangled with land politics in the Western US. According to Shelton, writing about land ownership in nineteenth century California, the question of land ownership in both California and other Western states was deeply connected to "the survival of the white race" (Shelton, 2013, p. 98). Here, whiteness was defined by a particular type of relationship to land, a relationship threatened by "emancipated slaves and immigrants” (Shelton, 2013, p. 98).

Leaders of the Burns Paiute Tribe could not have been more vocal in their disagreement with the Bundys' methods and ideas about who rightfully owns the land at Malheur. While the tribe has its own issues with federal regulations--in 2016 the tribe noted that the government had "become increasingly bureaucratic about allowing the tribe to catch trout, bass and perch in the rivers lacing the mountains and to hunt elk and deer in the woods"--they preferred a much different approach to the one taken by the Bundys (Allen, 2016, n.p.). Chairwoman Charlotte Roderique, in response to the takeover, said "we don't want people who have no interest in this country at all in here, ramrodding their way through things and possibly being destructive" (qtd. in Allen, 2016, n.p.). Council member Jarvis Kennedy put it more bluntly, saying that the Bundys and their supporters "just need to get the hell out of here" (qtd. in Sidner, 2016, n.p.). Roderique had no doubts about who the Bundys thought the land's "rightful owners" were, saying "For them to say they want to give the land back to their rightful owners-well, I just had to laugh at that. When they talk about returning land, I know they didn't mean us. When [the US government] wanted us to give up the land, we didn't do it. We have never given up our aboriginal rights there. We do as well feel there-because this is still our land" (qtd. in Glionna, 2016, n.p.). Roderique further explained that the tribe still use the land for religious and ceremonial purposes, for gathering plants for traditional medicines, and visit protected sites (Glionna, 2016). Council member Selena Sam put it succinctly: "the land belongs to the Paiute here" (qtd. in Allen, 2016, n.p.). Seemingly, however, the claims of the Burns Paiute to the land and the ways in which they use it fall short of the Bundys' settler colonial understandings of proper claims and use: though there was a hasty attempt by the Bundys to incorporate the Burns Paiute into their occupation, the "occupiers only saw the land as being historically Indigenous at best. In other words, [the Burns Paiute] had a legitimate claim over the past-but not of the land in the present" (Sam, 2018, p. 78). Put differently, land is a marker of race in the Bundys' rhetorics because race can be used to determine one's relationship with land ownership. Indigenous peoples may have historical claims, but white settlers have the present-day claim to the land.

\footnotetext{
${ }^{13}$ Gender is, of course, also important here. Courtney Irons argues that "By pitting the federal government against the ranchers, the occupation places the dispute over land management policy squarely in terms of a dispute over control. because the federal government has control, the Bundys do not." Claiming ownership of the land is one way in which the Bundys preserve control over their livelihoods, their families, and their "male sovereignty" (2018, pp. 503 and 490).
} 
Defining land ownership in terms of race is thus one way in which power manifests; whomever owns the land controls everything else. From the perspective of settler colonial logics of property, the question of who is the rightful beneficiary of land/ power is easy to answer. Inwood and Bonds (2017) note that, in the context of Oregon specifically, the development of the state was "formulated on a white settler project premised on the eradication of Native peoples and the exclusion of other racialized minorities" (2017, p. 259). This historical note can be generalized to the other the Western states, especially in the context of land. Indeed, Ladino (2019) writes, the Bundys' occupation of MNWR shows that "white men are still seen as "belonging" on public lands, and the Indigenous erasure that allowed those lands to be deemed "public" in the first place continues" (2019, p. xi). In the settler colonial state, land is property, owned by white settlers. Land, and thus power, as the Bundys articulate the concepts, rightly belong to white people.

\section{LAND AND NATIVE ERASURE}

The third way in which the Bundys further the rhetorical operation of settler colonialism is by defining land in ways that continue the erasure of Indigenous peoples from that land. Carbaugh and Rudnick (2006) write that naming places is a "massively deep symbolic expression," and naming land as "private property" or "public land" is a settler strategy of overwriting the names and meanings that Indigenous peoples gave that land (2006, p. 183). Further, Stuckey and Murphy (2001) note the naming of land is a distinctly colonial project, a method of "rhetorical colonialism" which "undermines the political and cultural influence of Native Americans and asserts control over their lands and resources" (2001, p. 85). The governing imperative of settler colonialism is to acquire and retain land and, in order to meet this imperative, settler colonialism works to symbolically and materially erase the presence of Indigenous peoples from the land. From the settler perspective, Wolfe (2016) contends, Indigenous peoples obstructed "the expansion of settlement," and so "no effort was spared to eliminate them" from the land (2016, p. 3). A range of techniques are employed to remove the land's Indigenous inhabitants, what Wolfe (2006) refers to as "strategies of elimination" (2006, p. 401). By way of these techniques, Indigenous populations are removed from the land or assimilated into broader settler society. In the case of the former, physical elimination is required; the latter is the "not necessarily homicidal dissolution of Native difference into the settler mainstream" (Wolfe, 2016, p. 15). Settlers, moving onto Native peoples' lands, claimed those territories for themselves. No matter the specific technique, however, the ultimate desired outcome is the elimination of the Indigenous presence from the land. The result is land available for settlement. The Bundys' arguments about public lands work to further such strategies of erasure.

In this section, I focus on two specific strategies of elimination, that of making land ahistorical, and that of defining the land's uses. By ahistorical, I mean that land is often removed from its historical contexts in the Bundys' arguments about public lands, the government, and ownership. Just as their constitutional interpretation lacks historical accuracy, so too do their assumptions about the land they desire. Making land ahistorical allows the Bundys to fill in the subsequent gap and apply their own histories and meanings to the land. To make this argument, I build on the family's arguments about the Constitution and power. The second strategy, defining the land's uses, is the Bundys' way of further defining who is implicated in the land and decision-making about land. Here, the family insists on "local control," a euphemism for white settler control of the land. Ultimately, both strategies function as techniques of erasure, ensuring that Indigenous peoples are not implicated in the land.

\section{MAKING LAND AHISTORICAL}

Tuck and McKenzie (2015) note that making land ahistorical "reaffirms the myth of terra nullius," or the idea that the land was free, empty, and available for settlement (2015, p. 64). Importantly, this strategy holds that the history of the land begin with settlement. In this telling of history, Indigenous peoples were already gone when settlers arrived, voluntarily leaving the land behind as they moved elsewhere of their own accord. An example of this oft-repeated myth is the concept of wilderness. In the popular imagination, wilderness means a place deserving of preservation and protection because of its beauty, valued because it is uninhabited by humans. As Spence (1999) argues, however, "uninhabited wilderness had to be created before it could be preserved" (1999, p. 4). Making land ahistorical is a strategy of elimination, and erases Indigenous people because it intentionally disarticulates land and settlement with genocide and the violence of colonialism. The ahistoricity of land tells us that settlers never had to reckon with Indigenous peoples on the land, because those peoples were never there or, if they were there at one time, they willingly left before the settlers arrived.

The Bundys' claims about power, the constitutionality of federal land ownership, and race work to place land in a particular history, one which begins with the federal government having already acquired large tracts of land. In this telling, the government acquired land and then unconstitutionally decided to not dispose large portions of it, rather than selling the lands to private owners. The Bundys argue this should be remedied, and that "the legal and rightful control of the land belongs to the local people. It is time for our State and County representative to take control of the land. It is time that they dispose of the land to the people, open the land up for useful purposes" (2014b, n.p.). This selective history emphasizes the period when "the government took ownership of land not claimed during the settlement period, instead of the stage leading up to it, when the government seized the indigenous land it would use for settlement" (Gallaher, 2016, p. 295). That is, as told by the Bundys, public lands history begins with the federal government having already acquired nominally empty land and then selling and giving it to (predominantly white) settlers, a 
history that ignores the colonial past and present of public lands. To better understand the Bundys' telling of this history, consider this quote from Ryan Bundy:

In 1789 , the thirteen States were united under the newly signed Constitution. The original thirteen States had land that extended west of the Allegany Mountains, mostly unsettled. The States voluntarily and collectively decided to allow the central government (federal) to administer these lands. They called them Territories. The plan was for the federal government to administrate the Territories until they could become States. As the population grew due to westward expansion, Territorial lands were created into States. There is no question that the people in the original thirteen States owned the land within the State borders. There is no question that the central, or federal government, had no right to any land within the several States (2015c, n.p.).

Bundy is here arguing that the lands "west of the Allegany Mountains" already belonged to the United States. This history begins with Indigenous peoples having already been dispossessed of the lands, because these land were "mostly unsettled." The narrative Ryan tells sets the land apart from anything that happened prior to the government taking ownership of it, e.g., the government removing the land's prior Indigenous inhabitants. Accounts like these make land ahistorical by ignoring how the federal government came to acquire the land in the first place.

As Gallaher (2016) notes, ahistorical frames like the one Ryan describes allows anti-government rhetorics like the Bundys' to argue that they are "reclaiming the people's land from the government rather than engaging in a second round of white theft of Indigenous land" (2016, p. 295). In the Bundys' view, public lands are the rightful property of private citizens that the government illegally retained. Put otherwise, the land became the rightful property of private citizens at the moment the federal government acquired control over it. At the moment of federal acquisition, it ceased being Native land, a fact over which the Bundys have no qualms. Indeed, the logic behind the Bundys' arguments is that the existence of federal public lands signals a state where Indigenous peoples lost their right to the land, and where white settlers have not yet received their claim to the land. Or, as Ammon put these ideas in the context of MNWR: "In 1908 President Theodore Roosevelt, in a political scheme, create an 'Indian reservation' around the Malheur, Mud \& Harney Lakes and declared it "as a preserve and breeding ground for native birds". Later this "Indian reservation" (without Indians) became the Malheur National Wildlife Refuge" (2015d, n.p.). Later in this same post, Ammon details the ways in which he believes the federal government has maintained control of the land around Malheur by driving away ranchers and their claims to private land. Ammon never questions why there would be an "Indian reservation without Indians," instead focusing on his belief that white settlers have lost their claims to the land.
The Bundys' conceit is that land's meanings have been held stable for much of the past century; that is, rather than recognizing the switch in federal policy from disposal of land to retention, the Bundys frame land as still freely available to private citizens, much like in the homesteading era. In this understanding, white settlers still have the predominant claim to land. Recognizing the emergence of retention as a constitutionally sound federal land policy would be a recognition that white settlers no longer have an inherent claim to the land. The Bundys do not want to realize a situation where white settlers have no more right to the land than Indigenous peoples who "lost" their claims.

\section{LAND USE}

The second strategy the Bundys use to continue the rhetorical erasure of Indigenous peoples from the land is by defining the land's proper uses and beneficiaries. This strategy includes defining who gets to use land, and what uses that land should be put toward. First, the family defines land uses in terms of "locals," a euphemism for white control of land. In Cliven Bundy's view, public lands do not belong to all Americans, nor should they be understood as "public" at all. Instead, these are the lands of the people who live on them, benefit from them, develop and improve them, and use the land; under settler colonialism, the white settler assumes their right to land through such "productive" uses. As Cliven wrote about his ranch lands, they are "the public land of the people of Clark County (Nevada)" (Bundy, 2012a, n.p.). Land is for locals, those who live on and near the land. From the perspective of settler colonialism, land becomes the property of those settlers who move in after the Indigenous inhabitants are removed. "Localism" is a settler colonial strategy where the differences between settlers and Indigenous peoples are whitewashed, and where settlers give themselves a claim to the land equal to that of the displaced Indigenous populations. Goodman (2016) argues that this strategy is a "mechanism of making settlers indigenous" to the land, where settlers overwrite the land's meaning through logics of property, control, ownership, and economic exploitation (2016, p. 16).

The family's definitions of correct land use are those that benefit private owners. The Bundys often describe land as a resource which should be put toward "useful purposes" that benefit human owners. Federal ownership of land restricts individuals from using the land for private benefit. Cliven, writing in 2012, argued that the federal government's land management practices often "managed to destroy human man's way to harvest and use the renewable resource" that the land provides (Bundy, 2012b, n.p.). The government, through regulating land use, are "trying to take the natural resources away from the people," the "greatest immediate threat to the individual person and the people as a whole" (Bundy, 2015a, n.p.; Bundy, 2015b, n.p.).

The family ascribes a symbiotic relationship to human land use, arguing that proper human uses of the land are beneficial to both humans and the land itself. Here, the Bundys are defining 
land in terms of resource productivity and their beliefs that certain uses--such as cattle grazing--benefit the land. For example, Cliven once claimed that cattle grazing makes certain plants makes them "productive," his term of choice in describing plants that are healthy and thriving (Gardner, 2015, n.p.). Crucially, according to Bundy, it is the human activity of grazing cattle on the land that creates this healthy environment. This was also not a one-time claim; in his narrative of the Hammonds incident and the history of the MNWR, Ammon Bundy made similar claims. In his telling, Ammon emphasized the improvements early settlers made to the area, his perception that the federal government has been trying to force ranchers out of the basin for several decades, and ultimately argues that the land's health has deteriorated as the government has become more and more involved in land use. In Ammon's telling, MNWR has seen near-constant conflicts over who gets to use the area, as well as how the land should be used. Ammon presents a picture of Harney Basin as place of fruitful and flourishing ranches--at least, until the government stepped in.

In his narrative, Ammon details a history of defining and redefining land, its uses, and its ownership. This post reflects a conviction that, when left to their own devices, ranchers and land users are more than capable of using land to the benefit of both humans and environment. Conversely, government-prescribed land uses are depicted as harmful. Ammon wrote that, when the Harney Basin was settled, the ranchers developed a "state of the art irrigated system to water the meadows" (Bundy, 2015d, n.p.). In his telling, this improved the land so much that it influenced the migratory patterns of birds (National fish and Wildlife Service, 2016). According to the National Fish and Wildlife Service, the refuge was established to protect birds from over-hunting by President Theodore Roosevelt in 1908 (2016). According to Ammon though, Roosevelt initially created the refuge as an Indian Reservation-- "without Indians"--in a "political scheme" (Bundy, 2015d, n.p.). Langston (2016) disagrees, writing that the Paiute reservation referenced by the Bundys existed before 1908, and was "without Indians" because they were removed by the government some years prior to ranchers settling in the area. White ranchers homesteaded on former Paiute land, and the wildlife refuge was later created from former reservation lands (Langston, 2016, n.p.). While Ammon does not agree with the historical details of the reservation, the Bundys and the government do both agree that the wildlife refuge serves as protection for birds. However, Ammon attributes the flourishing bird population to the ranchers. Because of the human-created habitat, he argues, the government stepped in and, starting with Roosevelt's political "plot," began a century-long attempt to wrest control of the Harney Basin from the ranchers. The plight of Dwight and Steven Hammond, the reason for the MNWR occupation, is proof that the government is still trying to gain full control of the Malheur area (Bundy, 2015d). For the Bundys and their followers, public lands should be managed in ways that promote certain land uses--those that benefit the private land owner.

Both of these strategies--that of making land ahistorical and that of defining the proper uses and beneficiaries of land--contribute to the rhetorical erasure of Indigenous people. Making land ahistorical accomplishes this erasure by telling a version of history where Indigenous people were never removed from their land, had left voluntarily, or were never there, reaffirming a myth of empty land. The Bundys further this myth and history by arguing that the federal government is required to give public lands to private citizens. The second strategy of erasure, defining the land's uses and beneficiaries, works to further settler colonialism's goals by arguing that white settlers are the proper beneficiaries of the land. Further, the Bundys' argue that the uses settlers put the land toward are beneficial to the land itself.

\section{CONCLUSION}

The Bundys' arguments about public lands demonstrate the rhetorical operation of settler colonialism. Settler colonialism remakes land, a process that I contend is fundamentally rhetorical. As the Bundys show, settler colonialism works to remake land through defining and redefining the land's meanings. Ultimately, settler colonialism remakes land in order to provide white settlers with a superior, inherent claim to the land. In this essay, I discussed three ways that the Bundys further this function of settler colonialism. First, I relayed the family's arguments about federal ownership of public lands. Here, the Bundys argue that the government is not constitutionally able to own large amounts of land and that the public lands should instead be transferred to private individuals. Connecting this section to settler colonialism, I showed how private property is a colonial logic that allows white settlers to presume their inherent right to the land. Second, I recounted how the Bundys racialized land ownership. Here, the family contends that ownership and control of land in the United States was founded on a principle of individual land ownership, a situation where land--and thus power--is primarily located in the hands of white settlers. Finally, I discussed the family's two primary strategies of continuing the rhetorical erasure of Indigenous people from the land. The first strategy is that of making land ahistorical, which allows the family to impose their own meanings onto the land. The second strategy is that of defining the land's beneficiaries and uses, which allows the family to define who land is for, what uses the land should be put toward, and who gets to be the beneficiary of land ownership.

The case of the Bundys and their occupation of Malheur National Wildlife Refuge is thus an important example of how public spaces are understood through logics of whiteness in the United States. My analysis of the Bundys and the lessons learned about whiteness, white masculinity, settler logics, and public space demonstrate the need for further analyses of similar events. Though the exact specifics of MNWR differed from the January 2021 occupation of the Capitol building, both events demonstrate the palpable privilege whiteness gave to both sets of occupiers as they interacted with and occupied public spaces. As largely white men, the provocateurs at both MNWR and the Capitol relied on their inherent privilege to occupy public space 
with little consequence. Further work might address similar questions as I did about the Bundys and land, and examine how public spaces are talked about, defined, and what meanings are given to these spaces. There is also a pressing need to examine how rhetorical processes have contributed to the violent work of settler colonialism and the erasure of Indigenous peoples. Indeed, as Lechuga (2020) notes, the discipline of rhetoric itself is deeply implicated in settler colonialism. The remaking of land, a fundamentally rhetorical process which is central to settler colonialism's strategies of Indigenous erasure, invites continued work.

\section{REFERENCES}

Allen, J. (2016). Oregon native tribe uneasy with armed standoff over land rights. Reuters. Available at: https://www.reuters.com/article/us-oregon-militia-tribe/oregon-native-tribeuneasy-with-armed-standoff-over-land-rights-idUSKBNOUK1FS20160106 (Accessed December 7, 2021).

Anti-Defamation League (2021). Anatomy of a Standoff: The Occupiers of the Malheur National Wildlife Refuge Headquarters. ADL. Available at: https:// www.adl.org/sites/default/files/documents/assets/pdf/combating-hate/Anatomyof-a-Standoff-MalheurOccupiers.pdf (Accessed December 7, 2021).

Battiste, M., and James, Y. H. (2008). Protecting Indigenous Knowledge and Heritage: A Global Challenge. Saskatoon, Saskatchewan: Purich Publishing.

Bernstein, M. (2021). Armed Occupation of Malheur Refuge Was 'dress Rehearsal' for Violent Takeover of Nation's Capitol, Extremist Watchdogs Say. The Oregonian/ Oregon Live. Available at: https://www.oregonlive.com/crime/2021/01/armedoccupation-of-malheur-refuge-was-dress-rehearsal-for-violent-takeover-of-nationscapitol-extremist-watchdogs-say.html (Accessed December 7, 2021).

Blumm, M. C., and Fraser, J. A. (2017). Coordinating with the Federal Government: Assessing County Efforts to Control Decisionmaking on Public Lands. Public Land Resour. L. Rev. 38, 1-56.

Blumm, M. C., and Jamin, O. (2016). The Property Clause and its Discontents: Lessons from the Malheur Occupation. Ecol. L. Q. 43, 4. doi:10.2139/ ssrn. 2817205

Boggs, K. (2019). "The Rhetorical Landscapes of the 'Alt Right' and the Patriot Movements," in The Far Right and the Environment: Politics, Discourse and Communication. Editor B. Forchtner (New York: Routledge), 293-309. doi:10.4324/9781351104043-17

Bonds, A., and Inwood, J. (2016). Beyond white Privilege: Geographies of white Supremacy and Settler Colonialism. Prog. Hum. Geogr. 40 (6), 715-733. doi:10.1177/0309132515613166

Brown, K. (2016). Outrage at Malheur, Standing Rock Is Predictable (Opinion). The Oregonian/Oregon Live (Accessed December 7, 2021). Available at: https:// www.oregonlive.com/opinion/2016/11/outrage_at_malheur_standing_ro. html.

Bundy (2012a). New Gold Butte' Wild Fire South of Mesquite, Nevada on April 26, 2012. Bundy Ranch. Available at: http://bundyranch.blogspot.com/search? updated-min=2012-01-01T00:00:00-08:00\&updated-max=2013-01-01T00:00: 00-08:00\&max-results=18 (Accessed December 7, 2021).

Bundy (2012b). Emergency: Constructive Notice and Demand for Protection. Bundy Ranch. Available at: http://bundyranch.blogspot.com/p/continuereading.html (Accessed December 7, 2021).

Bundy (2014a). Feds Retaliate against the Bundy Ranch and the Southern Nevada People. Bundy Ranch Blog, October 26, 2014. Available at: http://bundyranch. blogspot.com/2014/10/feds-retaliate-against-bundy-ranch-and.html (accessed April 19, 2017).

Bundy (2014b). They Must Say No! Bundy Ranch Blog. Available at: http:// bundyranch.blogspot.com/2014/10/they-must-say-no.html (Accessed December 7, 2021).

Bundy (2014c). Modern Day Conquers. Bundy Ranch. Available at: http:// bundyranch.blogspot.com/2014/ (Accessed December 7, 2021).

\section{DATA AVAILABILITY STATEMENT}

The original contributions presented in the study are included in the article/Supplementary Material, further inquiries can be directed to the corresponding author.

\section{AUTHOR CONTRIBUTIONS}

The author confirms being the sole contributor of this work and has approved it for publication.

Bundy (2015a). Protecting Our Natural Resources. Bundy Ranch. Available at: http://bundyranch.blogspot.com/2015/02/ (Accessed December 7, 2021).

Bundy (2015b). Five Most Concerns Facing America. Bundy Ranch. Available at: http:// bundyranch.blogspot.com/2015/03/five-most-concerns-facing-america.html (Accessed December 7, 2021).

Bundy (2015c). The Constitution of the United States on Federal Land Ownership. Bundy Ranch. Available at: http://bundyranch.blogspot.com/2015/12/theconstitution-of-united-states-on.html (Accessed December 7, 2021).

Bundy (2015d). Hammond Family Facts \& Events. Bundy Ranch. Available at: http://bundyranch.blogspot.com/2015/ (Accessed December 7, 2021).

Bundy (2016). Calling All Good Men and Women to Burns Oregon, Malheur Wildlife Refuge. Bundy Ranch. Available at: http://bundyranch.blogspot.com/ 2016/01/calling-all-good-men-and-women-to-burns.html (Accessed December 7, 2021).

Carbaugh, D., and Rudnick, L. (2006). Which Place, What Story? Cultural Discourses at the Border of the Blackfeet Reservation and Glacier National Park. Great Plains Q. 26 (3), 167-184.

Chappell, B. (2018). Trump Pardons Ranchers Dwight and Steven Hammond Over 2012 Arson Conviction. NPR. Available at: https://www.npr.org/ 2018/07/10/627653866/president-trump-pardons-ranchers-dwight-andsteven-hammond-over-arson (Accessed December 7, 2021).

Chason, R., and Schmidt, S. (2021). Lafayette Square, Capitol Rallies Met Starkly Different Policing Response. The Washington Post. Available at: https:/www.washingtonpost.com/dc-md-va/interactive/2021/blm-protestcapitol-riot-police-comparison/ (Accessed December 7, 2021).

Christiansen, J. (2021). The Water Protectors at Standing Rock: Survivance Strategies for Gendered Relinking. Women's Studies in Communication. 44 (3), 278-300. doi:10.1080/07491409.2020.1834037

Clark, G. (2004). Rhetorical Landscapes in America: Variations on a Theme from Kenneth Burke. Columbia: University of South Carolina Press.

Dare, A. M., and Fletcher, C. V. (2019). A Bird's Eye View of the Malheur Wildlife Refuge Occupation: Nonhuman Agency and Entangled Species. Environ. Commun. 13 (3), 412-423. doi:10.1080/ 17524032.2017 .1412998

Druschke, C. G. (2013). Watershed as Common-Place: Communicating for Conservation at the Watershed Scale. Environ. Commun. 7 (1), 80-96. doi:10.1080/17524032.2012.749295

Eisenberg, A. M. (2017a). Alienation and Reconciliation in Social-Ecological Systems. Environ. L. 47 (1), 127-178.

Eisenberg, A. M. (2017b). Do Sagebrush Rebels Have Colorable Claim: The Space between Parochialism and Exclusion in Federal Lands Management. Public Land Resour. L. Rev. 38, 57-102.

Endres, D., and Senda-Cook, S. (2011). Location Matters: The Rhetoric of Place in Protest. Q. J. Speech 97 (3), 257-282. doi:10.1080/00335630.2011.585167

Endres, D. (2012). Sacred Land or National Sacrifice Zone: The Role of Values in the Yucca Mountain Participation Process. Environ. Commun. 6 (3), 328-345. doi:10.1080/17524032.2012.688060

Estes, N. (2021). Only Racist Ignorance Lets Rick Santorum Think America Was 'Birthed from Nothing'. The Guardian. Available at: https://www. theguardian.com/commentisfree/2021/apr/27/only-racist-ignorance-letsrick-santorum-think-america-was-birthed-from-nothing (Accessed December 7, 2021). 
Fantz, A., Sutton, J., and Yan, H. (2016). Armed Group's Leader in Federal Building: 'We Will Be Here as Long as it Takes. CNN. Available at: http:// www.cnn.com/2016/01/03/us/oregon-wildlife-refuge-protest/ (Accessed December 7, 2021).

Fitzsimmons, T. (2021). Rick Santorum Says 'There Isn't Much Native American Culture in American Culture. NBC News. Available at: https://www.nbcnews.com/news/us-news/rick-santorum-says-there-isn-tmuch-native-american-culture-n1265407 (Accessed December 7, 2021).

Gallaher, C. (2016). Placing the Militia Occupation of the Malheur National Wildlife Refuge in Harney County, Oregon. ACME: Int. J. Crit. Geographies 15 (2), 293-308. Available at: https://www.acme-journal.org/index.php/acme/ article/view/1312.

Gardner, C. (2015). Who Are the Dummies Here? Is it Us, or the 'Experts'? Bundy Ranch. Available at: http://bundyranch.blogspot.com/2015/01/who-aredummies-here-is-it-us-or-is-it.html (Accessed December 7, 2021).

Gates, P. W., and Swenson, R. W. (1968). History of Public Land Law Development. Washington: U.S. Government Print Office. Available at: https://hdl.handle. net/2027/uc1.32106000891595.

Glionna, J. M. (2016). How the Oregon Militia Standoff Became a Battle with a Native American Tribe. The Guardian. Available at: https://www.theguardian. com/us-news/2016/jan/06/oregon-militia-malheur-wildlife-refuge-paiuteindian-tribe-sacred-land (Accessed December 7, 2021).

Goodman, C. (2016). Reclaiming the Land: Indigenous Articulations of Environmentalism at Bears Ears. Master's Thesis. Albuquerque, NM: University of New Mexico.

Gruber, D. R. (2020). The Theatricality of Lion Rock: A New Materialist Theory for Events of Dissention. Q. J. Speech 106 (4), 453-469. doi:10.1080/ 00335630.2020 .1828607

Hutchins, K., and Stormer, N. (2013). Articulating Identity in and through Maine's North Woods. Environ. Commun. 7 (1), 24-41. doi:10.1080/ 17524032.2012.749412

Ingalls, M. L., Kohout, A., and Stedman, R. C. (2019). When Places Collide: Power, Conflict and Meaning at Malheur. Sustain. Sci. 14, 625-638. doi:10.1007/ s11625-019-00689-6

Inwood, J. F. J., and Bonds, A. (2017). Property and Whiteness: The Oregon Standoff and the Contradictions of the U.S. Settler State. Space and Polity 21 (3), 253-268. doi:10.1080/13562576.2017.1373425

Irons, C. (2018). The Patriarch and the Sovereign: The Malheur Occupations and the Hyper-Masculine Drive for Control. Columbia J. L. Soc. Probl. 51 (3), 479-522.

Johnson, K., and Healy, J. (2016). Protesters in Oregon Seek to End Policy that Shaped West. New York Times. Available at: http://www.nytimes.com/2016/ 01/06/us/protesters-seek-to-end-policy-that-shaped-west.html (Accessed December 7, 2021)

Johnson, P. E. (2017). The Art of Masculine Victimhood: Donald Trump's Demagoguery. Women's Stud. Commun. 40 (3), 229-250. doi:10.1080/ 07491409.2017.1346533

Johnson, T. N. (2019). The Dakota Access Pipeline and the Breakdown of Participatory Processes in Environmental Decision-Making. Environ. Commun. 13 (3), 335-352. doi:10.1080/17524032.2019.1569544

Keeler, J. (2017). Edge of Morning: Native Voices Speak for Bears Ears. Salt Lake City: Torrey House Press.

Kelly, C. R., and Neville-Shepard, R. (2020). Virgin Lands: Gender, Nature, and the Frontier Myth in David Magnusson's Purity. Women's Stud. Commun. 43 (1), 1-22. doi:10.1080/07491409.2019.1696436

Ketcham, C. (2015). The Great Republican Land Heist. Harper's Magazine. Available at: https://harpers.org/archive/2015/02/the-great-republican-landheist $/$ ?single $=1$ (Accessed December 7, 2021).

King, T. L. (2019). The Black Shoals: Offshore Formations of Black and Native Studies. Durham: Duke University Press.

Ladino, J. (2019). Setting the Stage for Justice: The Politics of Public Lands in the Contemporary US West. West. Am. Lit. 54 (1), ix-xv. doi:10.1353/wal.2019.0015

Langston, N. (2016). In Oregon Myth Mixes with Anger. The New York Times. Available at: https://www.nytimes.com/2016/01/06/opinion/in-oregon-mythmixes-with-anger.html (Accessed December 7, 2021).

Lechuga, M. (2020). An Anticolonial Future: Reassembling the Way We Do Rhetoric. Commun. Critical/Cultural Stud. 17 (4), 378-385. doi:10.1080/ 14791420.2020 .1829659
LeMenager, S., and Weisiger, M. (2019). Revisiting the Radical Middle (What's Left of it). West. Am. Lit. 54 (1), 1-18. doi:10.1353/wal.2019.0016

Levin, S. (2016). Dakota Access Pipeline Protesters See Bias after Oregon Militia Verdict. The Guardian. Available at: https://www.theguardian.com/us-news/ 2016/oct/30/dakota-access-pipeline-protest-north-dakota-oregon-militianative-americans (Accessed December 7, 2021).

Liboiron, M. (2021). Pollution Is Colonialism. Durham: Duke University Press. Lopez, G. (2016). The Bundys, the Family Behind the Oregon Militia Standoff, Explained. Vox. Available at: http://www.vox.com/2016/1/5/10716462/bundyfamily-ammon-cliven-oregon-militia (Accessed December 7, 2021).

Morgan, L. (2019). "Trespassingin Sovereign Territory": Place, Patriarchy, and the Ideology of Public Lands in Longmire. West. Am. Lit. 54 (1), 19-35. doi:10.1353/wal.2019.0017

National fish and Wildlife Service (2016). About the Refuge. Available at https:// www.fws.gov/refuge/Malheur/about.html (Accessed December 7, 2021).

Neville-Shepard, R., and Kelly, C. R. (2020). Whipping it Out: Guns, Campaign Advertising, and the White Masculine Spectacle. Crit. Stud. Media Commun. 37 (5), 466-479. doi:10.1080/15295036.2020.1813902

O'Byrne, M., and Endres, D. (2021). This Land Is Our Land: Protesting to Protect Places on the Margin. Environ. Commun. 15, 887-903. doi:10.1080/ 17524032.2021.1911824

Peacher, A. (2016). Tribe Denounces Malheur Refuge Occupation. Oregon Public Broadcasting. Available at: https://www.opb.org/news/series/burns-oregonstandoff-bundy-militia-news-updates/tribe-denounces-malheur-refugeoccupation-/ (Accessed December 7, 2021).

Robbins, W. G. (2016). The Malheur Occupation and the Problem with History. Oreg. Hist. Q. 117 (4), 574-603. doi:10.5403/oregonhistq.117.4.0574

Rushing, J. H. (1989). Evolution of "The New Frontier" in Alien and Aliens: Patriarchal Co-optation of the Feminine Archetype. Q. J. Speech 75 (1), 1-24. doi:10.1080/00335638909383859

Sam, D. (2018). Indigenous Perspectives on the Occupation of Malheur: Comparing Contemporary Responses from Indigenous and Non-Indigenous Sources. [Bachelor's Thesis]. Eugene OR: University of Oregon.

Segerstrom, C. (2021). The Washington, D.C., Siege Has Western Roots and Consequences. High Country News. Available at: https://www.hon.org/ issues/53.2/north-extremism-the-washington-d-c-siege-has-western-rootsand-consequences (Accessed December 7, 2021).

Shaw, S. M. (2016). What the Malheur Occupation Teaches Us about Masculinity. Huffpost. Available at: https://www.huffpost.com/entry/what-malheuroccupation-patriarchy-masculinity_b_9116064 (Accessed December 7, 2021).

Shelton, T. V. (2013). A Squatter's Republic: Land and the Politics of Monopoly in California, 1850-1900. Berkeley: University of California Press.

Sidner, S. (2016). Native Tribe Blasts Oregon Takeover. CNN. Available at: https:// www.cnn.com/2016/01/06/us/native-tribe-blasts-oregon-takeover/index.html (Accessed December 7, 2021).

Siegler, K. (2016). Oregon Occupation Unites Native American Tribes to Save Their Land. NPR. Available at: https://www.npr.org/2016/10/27/499575873/ oregon-occupation-unites-native-american-tribes-to-save-their-land (Accessed December 7, 2021).

Siegler, K. (2021). Roots Of U.S. Capitol Insurrectionists Run through American West. NPR. Available at: https://www.npr.org/2021/01/12/955665162/roots-ofu-s-capitol-insurrectionists-run-through-american-west (Accessed December 7, 2021).

Skillen, J. R. (2020). This Land Is My Land: Rebellion in the West. New York: Oxford University Press.

Smith, S. L. (2016). Federal Ownership of Land in Oregon and Other States West of the Mississippi. Harney County. Available at: https://www.co.harney.or.us/ PDF_Files/County\%20Court/public\%20land\%20issues/Federal\%20Ownership \%20of\%20Public\%20Lands.pdf (Accessed December 7, 2021).

Spence, M. D. (1999). Dispossessing the Wilderness: Indian Removal and the Making of the National Parks. New York: Oxford University Press.

Stelte, B. (2021). Rick Santorum Departs CNN after Criticism of Native American Comments. CNN. Available at: https://www.cnn.com/2021/05/22/media/ricksantorum-cnn-departure-native-american-criticism/index.html (Accessed December 7, 2021).

Stuckey, M. E., and Murphy, J. M. (2001). By Any Other Name: Rhetorical Colonialism in North America. Am. Indian Cult. Res. J. 25 (4), 73-98. doi:10.17953/aicr.25.4.m66w143xm1623704 
Taylor, D. E. (2016). The Rise of the American Conservation Movement: Power, Privilege, and Environmental Protection. Durham: Duke University Press.

The Oregonian/Oregon Live (2016). Faces of the Malheur Occupation: Meet the Militants and Their Visitors. The Oregonian/Oregon Live. Available at: https:// www.oregonlive.com/pacific-northwest-news/2016/01/oregon_militant_profiles_ list.html (Accessed December 7, 2021).

Tsosie, R. (2018). "Indigenous Peoples and 'Cultural Sustainability': The Role of Law and Traditional Knowledge," in Traditional Ecological Knowledge: Learning from Indigenous Practices for Environmental Sustainability. Editors M. K. Nelson and D. Shilling (Cambridge: Cambridge UP), 229-249.

Tuck, E., and McKenzie, M. (2015). Place in Research Theory. New York: Taylor \& Francis.

Tuck, E., and Yang, K. W. (2012). Decolonization Is Not a Metaphor. Decolonization: Indigeneity, Educ. Soc. 1 (1), 1-40.

Walker, P. (2016). Malheur Occupation Is over, but the War for America's Public Lands Rages on. The Conversation. Available at: https://theconversation.com/malheuroccupation-is-over-but-the-war-for-americas-public-lands-rages-on-54943 (Accessed December 7, 2021).

Whyte, K. (2018). Settler Colonialism, Ecology, and Environmental Injustice. Adv. Res. 9, 125-144. doi:10.3167/ares.2018.090109

Wiles, T. (2016). Malheur Occupation Impacts Linger throughout the West. Available at: https://www.hcn.org/articles/ammon-bundy-malheur-standoffeffects-sagebrush-rebellion (Accessed December 7, 2021).

Wolf, C., Holley, P., and Lowrey, W. (2016). Armed Men, Led by Bundy brothers, Take over Federal Building in Rural Oregon. The Washington Post. Available at: https://www.washingtonpost.com/news/post-nation/wp/2016/01/03/ armed-militia-bundy-brothers-take-over-federal-building-in-rural-oregon/ (Accessed December 7, 2021).

Wolfe, P. (1999). Settler Colonialism and the Transformation of Anthropology: The Politics and Poetics of an Ethnographic Event. New York: Cassell \& Co.

Wolfe, P. (2006). Settler Colonialism and the Elimination of the Native. J. Genocide Res. 8 (4), 387-409. doi:10.1080/14623520601056240

Wolfe, P. (2016). Traces of History: Elementary Structures of Race. London: Verso. Yachnin, J. (2021). Bundy to Biden: Stay Away from My Cattle. E\&E News. Available at: https://www.eenews.net/stories/1063722595 (Accessed December 7, 2021).

Zellmer, S. B. (2019). Mitigating Malheur's Misfortunes: The Public Interest in the Public's Public Lands. Georgetown Environ. L. Rev. 31 (3), 509-562.

Conflict of Interest: The author declares that the research was conducted in the absence of any commercial or financial relationships that could be construed as a potential conflict of interest.

Publisher's Note: All claims expressed in this article are solely those of the authors and do not necessarily represent those of their affiliated organizations, or those of the publisher, the editors and the reviewers. Any product that may be evaluated in this article, or claim that may be made by its manufacturer, is not guaranteed or endorsed by the publisher.

Copyright (C) 2021 Smith. This is an open-access article distributed under the terms of the Creative Commons Attribution License (CC BY). The use, distribution or reproduction in other forums is permitted, provided the original author(s) and the copyright owner(s) are credited and that the original publication in this journal is cited, in accordance with accepted academic practice. No use, distribution or reproduction is permitted which does not comply with these terms. 